\title{
Language learner autonomy and the European Language Portfolio: Two L2 English examples
}

\author{
David Little Trinity College Dublin, Ireland \\ dlittle@tcd.ie
}

This article argues that the Council of Europe's European Language Portfolio is capable of supporting the implementation of language learner autonomy on a large scale. It begins by explaining what the author understands by 'language learner autonomy', then introduces the European Language Portfolio and explains how it can stimulate reflective learning in which goal setting and self-assessment play a central role. It concludes by giving two practical examples that involve the learning of L2 English in Ireland, in one case by adult immigrants with refugee status and in the other by newcomer pupils in primary schools.

\section{Introduction}

'Learner autonomy in language learning: Widening the circle' - I assume that the title of this event is intended to provoke and perhaps answer the question: How can we extend the practice of learner autonomy in language classrooms without investing in impossibly expensive and complex programmes of in-service teacher training? As my own title is intended to imply, I believe the European Language Portfolio (ELP) offers an answer to this question. I've been very much involved with the ELP at European level since the pilot phase at the end of the 1990s, and from an early stage it became evident that the ELP could have a transformative impact on language learning. In the Czech Republic, for example, where large numbers of teachers of Russian were suddenly required to become teachers of English, the ELP provided them with the means to develop learner-centred and reflective teaching approaches (for some examples, see Little \& Perclová 2001).

I want to begin by summarizing my view of language learner autonomy. Back in 1990 I predicted that learner autonomy was set to become a buzz word and that - like 'communicative' - it would soon be emptied of any clearly agreed meaning (Little 1991: 2). As a result, it is necessary repeatedly to explain what one understands by language learner autonomy, and what the processes are that one imagines underpin its development and practice. I shall then talk about the ELP in relation to the concept of learner autonomy, 
which the Council of Europe first introduced into discussion of language teaching and learning more than a quarter of a century ago. And after that I shall give two examples: one involves adult immigrants learning L2 English in Ireland; the other, learners of L2 English in Irish primary schools.

\section{Language learner autonomy}

In formal educational contexts autonomous language learners are able to take charge of their own learning; that seems to have been universally agreed since Henri Holec's report Autonomy and foreign language learning (cited here as Holec 1981) was first published by the Council of Europe in 1979. Autonomous learners also develop a capacity for 'detachment, critical reflection, decision making and independent action' (Little 1991: 4); they can manage the affective dimension of their learning experience to their motivational advantage (Ushioda 1996); and they become more autonomous in language learning in proportion as they become more autonomous in language use, and vice versa (Little 1991).

I've always been worried about discussions of learner autonomy that run away with the idea of freedom: I don't believe that to be autonomous is to be $100 \%$ free. People who are ENTIRELY free and detached from all responsibility are not autonomous, they are autistic (see, e.g., Frith 1989). That always gets a laugh, but it's not intended to: it's a perfectly serious point, because to the extent that we're not living under some socio-pathological handicap, we are social beings, our independence is always balanced by dependence, and our essential condition is one of interdependence. That helps to explain why it is that, like the acquisition of a language, the development of learner autonomy depends on social interaction. And that's where the socio-historical, socio-cultural theory that derives from the work of Vygotsky fits into the picture (e.g., Lantolf 2000, Lantolf \& Thorne 2006). This line of argument leads me to say that autonomous learners always do things for themselves, but they may or may not do things on their own.

Pedagogies that succeed in developing learner autonomy as I've defined it do so, I believe, because they answer a basic human need. According to Edward Deci (1995), human beings have three fundamental social-psychological needs: to be autonomous, that is, to set their own agenda and follow it through; to feel competent in what they do; and to be assured of their relatedness to other people. The power of this apparently inborn imperative to be autonomous is something that every parent has experienced. The point is well made by Phillida Salmon in the following description of the realities of family life:

To parents, even babies seem to have a will of their own; they are hardly passive creatures to be easily moulded by the actions of others. From their earliest years, boys and girls make their active presence, their wilful agency, their demands and protests, very vividly felt. In every household that has children, negotiations must be made with young family members: their personal agendas have somehow to be accommodated. (Salmon 1998: 24)

In those parts of our lives that are untouched by education, most of us achieve autonomy without conscious awareness or effort. By contrast, the development of autonomy in formal learning is generally a matter of deliberate effort and conscious reflection precisely because 
formal learning itself can happen only on the basis of explicit plans and intentions, which is one of the reasons why the teacher plays an essential role. I have argued elsewhere (e.g., Little $2001,2007)$ that the teacher's role is shaped by three pedagogical principles. First, there's the principle of learner involvement - we have to involve learners fully in planning, monitoring and evaluating their own learning. Then there's the principle of learner reflection we must help learners to reflect continuously on the process and content of their learning and to engage in regular self-assessment. And thirdly, there's the principle of target language use - we must ensure that the target language is the medium as well as the goal of learning, including its reflective component. These three principles describe at a very general level the things teachers have to do to create and sustain an autonomous language learning community. Together they create a framework within which the individual teacher must select (or develop) and implement an approach appropriate to the age, proficiency level, focus and goals of her learners.

According to these principles, in autonomy classrooms the target language is the preferred medium of communication, which means that the teacher has to scaffold negotiation with and between learners, insisting that they participate actively in the process. If she just talks to them in the target language, she won't get anything back, especially if they're beginners. The teacher also involves her learners in a non-stop quest for good learning activities, which means that she must help them to develop criteria for critical evaluation: Is this really a good learning activity? Why? Can you say what you think you learned from it? And so on. Within whatever larger agenda is imposed by the official curriculum, autonomous learners set their own goals and choose their own learning activities, which means that the teacher must help them to be focused in their aims and realistic in their choices. In an autonomous classroom, individual learning goals are pursued partly via collaborative group work (where dialogue mediates between the need to be autonomous and the need for relatedness), so the teacher must show her learners how to support one another in collaborative discourse. All learners keep an individual written record (journal or logbook) of their learning, which facilitates a focus on form, encourages memorization, and supports what can be a very powerful two-way interaction between speaking and writing (using interactive speech to generate written text; using written text as a prompt for speaking). Finally, all aspects of learning are regularly evaluated in the target language by the whole class, by groups of learners, and by individual learners in their logbook, which means that to begin with it must be done in very simple terms. That, very rapidly sketched, is the framework within which I operate (see also Dam 1995).

When it comes to implementing language learner autonomy on a larger scale, we run into three challenges. The first is teacher doubt: 'It may be alright for learners of English in Denmark, but you can't do it with learners of French in Dublin.' That kind of response is often a cover for the second challenge, which is lack of teacher know-how. And the third challenge is the supposed tyranny of the curriculum and/or the textbook and/or the exam: 'I know I ought to get these kids to talk to one another in German, because that's the only way they're going to become at all proficient, but I've got to get through the textbook and prepare them for the exam.' It's my purpose in this talk to suggest that the ELP, which gives a very specific shape to the learning journal or logbook, can help us to respond successfully to these challenges. 


\section{Language learner autonomy and the ELP}

So let me first say something about the relation between the ELP and learner autonomy as I have been talking about it. To do that it's necessary to begin with the Common European Framework of Reference for Languages (CEFR), which was developed to provide 'a common basis for the elaboration of language syllabuses, curriculum guidelines, examinations, textbooks, etc. across Europe' (Council of Europe 2001: 1; see also Little 2006). It was intended, in other words, to stimulate debate, comparison, and collaboration. For those not familiar with it, it comprises a complex apparatus for describing L2 proficiency at six levels (A1 and A2 - basic user; B1 and B2 - independent user; C1 and C2 - proficient user) in relation to five communicative activities: listening, reading, spoken interaction, spoken production and writing. Following the Council of Europe's tradition of three decades, the CEFR embodies an action-oriented approach to language use that may be summarized as follows.

- We use language to perform communicative acts, which may be external and social (communicating with other people) or internal and private (communicating with ourselves).

- Communicative acts comprise language activity, which is divided into four kinds: reception, production, interaction and mediation.

- In order to engage in language activity, we draw on our communicative language competence.

- Language activity always occurs in a context that imposes conditions and constraints.

- Because we must cope with often unpredictable contextual features, our communicative language competence has sociolinguistic and pragmatic components.

- Language activity entails the performance of tasks, and to the extent that they are not routine or automatic, those tasks require us to use strategies in order to understand and/or produce spoken or written texts.

A more complex version of this summary is to be found in the text box at the beginning of chapter 2 of the CEFR (Council of Europe 2001: 9).

An important point to add here is that the CEFR's action-oriented approach assigns a central role to language use in language learning: 'Language use, embracing language learning, comprises the actions performed by persons who as individuals and as social agents develop a range of competences' (ibid.). Thus the 'I can' descriptors of the self-assessment grid (ibid.: 26-27) and the 'can do' descriptors of the CEFR's illustrative scales characterize the autonomous L2 user - autonomous precisely because they say what he or she can do but also, by extension, the autonomous language learner.

The European Language Portfolio was conceived as a companion piece to the CEFR. It reflects the Council of Europe's concern with (among other things) the development of the language learner and his or her capacity for what the CEFR calls independent language learning. According to the principles and guidelines that define the ELP (Council of Europe 2006), it's the property of the learner and a tool to promote learner autonomy. It encourages indeed, it doesn't work without - frequent goal-setting, monitoring and self-assessment; so it is connected in various ways with the concept of learner autonomy that I've sketched for you. 
The ELP has three obligatory components: a language passport, a language biography, and a dossier. It uses the proficiency levels of the CEFR in two ways: in summary form (usually the self-assessment grid; Council of Europe 2001: 26-27) in the language passport, which the owner updates at regular intervals, for example at the end of a semester or a school term, to provide a summary of his or her experience of learning and using second languages; and in the form of 'I can' checklists (usually found in the language biography and arranged according to language activity and proficiency level), which the owner uses to identify learning targets, monitor learning progress, and assess learning outcomes.

In principle the ELP can support the autonomy classroom in three ways. First, when the checklists reflect the demands of the official curriculum they provide learners and their teachers with an inventory of learning tasks that they can use to plan, monitor and evaluate learning over a school year or a term or a month or (sometimes) just a week. Secondly, the language biography is explicitly designed to associate goal setting and self-assessment with reflection on learning styles, learning and communication strategies, and the cultural dimension of L2 learning and use. And thirdly, when the ELP is presented partly in the learner's target language, it can help to promote the use of the target language as medium of learning and reflection. One of the ELPs that we've developed in Ireland is for secondaryschool learners of foreign languages (Authentik 2001), and it arose from a project designed to explore ways of fulfilling the requirement of the official curriculum, all too often ignored, to develop learner autonomy. In other words, we designed this ELP as a dissemination tool for our project. One of the teachers who participated in the pilot implementation reported that she had found it all but impossible to get her 15-year-old learners to use French in the classroom until she presented them with 'I can' checklists in French. They immediately recognized that these were a resource for talking about their learning goals and achievements in the target language, and speaking to one another in French no longer seemed impossible. (For a report on the CLCS Learner Autonomy Project, see Little, Ridley \& Ushioda 2002; for an account of the preliminary piloting of this ELP, see Ushioda \& Ridley 2002.)

\subsection{Adult immigrants learning L2 English in Ireland}

The Irish government provides free English language courses for adult immigrants to whom it grants refugee status or humanitarian leave to remain in the country. Responsibility for designing and delivering these programmes lies with Integrate Ireland Language and Training (IILT), a not-for-profit campus company of Trinity College Dublin. ${ }^{1}$ In 2006, 925 learners attended courses in Dublin and thirteen other centres around Ireland. Most learners attend classes for between six and twelve months before either finding employment or moving on to further education or training.

Students at IILT must learn as much English as they can in the shortest possible time so that they can get on with their lives as members of an English-speaking society. In other

\footnotetext{
${ }^{1}$ This was the situation at the time this talk was given. In June 2008 the Department of Education and Science informed the directors of IILT that it had decided to mainstream IILT's activities and divert funding to other agencies. IILT ceased operations in August 2008.
} 
words, courses have to respond in a very immediate way to students' objective and subjective needs: the needs imposed on them by building a new life in Ireland, but also the needs that come from their personal agenda. Courses therefore emphasize language learning through language use and they also seek to develop language learner-users who will be capable of creating their own learning opportunities after the end of their course.

Students come from many different ethnic and linguistic backgrounds (in 2006 we had more than 60 nationalities), and between them they have a wide range of educational experience and achievement, so classes are never homogeneous. Most students, nevertheless, begin with the same expectation: that they're going to sit more or less passively in the classroom while their teacher teaches them. So what about our pedagogical approach? We expect our teachers to create an autonomous classroom along the lines that I've described. There's no pre-existing curriculum; instead teachers are required to negotiate each term's programme with their students. In most audiences to whom I describe our practice there's at least one person who asks, 'How can you do that with complete beginners?' The answer is that the teacher negotiates with complete beginners by exploiting whatever communicative resources are available in the class and using pictures to refer to the different social and bureaucratic domains that students have to cope with. As the term progresses, teachers help students at all levels to develop individual learning agendas within evolving class agendas, and learning is supported by a highly flexible classroom dynamic - some things are done by the whole class working together, some by groups of learners, and some by individuals working on their own.

As this perhaps already implies, we don't use textbooks, for two reasons. First, most textbooks available in Ireland assume that the learner wants to cope with British society, but there's no point in having our students learn how to ask for directions on the London Underground when what they really need to know is how to cope with taking a sick child to the doctor. Secondly, textbooks all too easily serve to constrain classroom discourse, whereas we want to draw our students into rich, unpredictable and open interaction that reflects the nature and scope of the communicative challenges they encounter outside the classroom. Thus, we make a lot of use of authentic materials - information leaflets, application forms, and so on; and we encourage students to work together to devise learning materials and activities that suit their own learning agendas.

At a very early stage, partly to make up for the absence of textbooks, we devised our own versions of the ELP to provide teachers and students with a common framework for teaching and learning; and in due course we developed the Milestone ELP in collaboration with colleagues teaching the language of the host community to immigrants in Germany, The Netherlands, Sweden and Finland. The Milestone ELP begins not with the language passport but with the language biography, which is divided into two parts. The first part focuses on previous language learning and intercultural experiences, important events in the learner's life, and his or her starting proficiency in the host community language. It has turned out to be important in terms of raising students' self-esteem, but also productive in terms of teaching and learning, to do as much as we can to draw individual experiences into the common knowledge resource of the class. Milestone colleagues contributed interesting ideas that certainly hadn't occurred to us. The Dutch group, for example, introduced the language biography page on which the learner summarizes his or her past life as a timeline. In their original proposal the timeline went from 0 to 40 - more than enough if most of your 
learners are under 25, but it wasn't much use to us because at the time our oldest student was a 77-year-old refugee from Afghanistan; so it was agreed to extend the timeline from 0 to 100 . The second part of the language biography focuses on current language learning attitudes, expectations, learning contract, learning style, personal learning goals, the 'I can' checklists and self-assessment. This isn't something that people sit down with and fill out like an income tax return; rather, it is drawn into the interaction of the classroom from day to day and week to week. In many ELPs the dossier is simply an open form which can be filled with samples of work, work in progress, or a learning journal. The dossier in the Milestone version can be used in the same way, of course, but we also gave it some structured content; for example, there is a page on which learners kept their own attendance record. The last element in the Milestone ELP is the language passport, which is the so-called standard adult passport that the Council of Europe recommends for use with all ELP models designed for older adolescents and adults.

In introducing the Milestone ELP we wanted to develop an institutional ELP culture. All IILT's teachers and students must use the Milestone ELP; it's not a matter of choice. At the same time, teachers are entirely free to introduce and exploit the ELP in whatever way best suits their teaching style and the level of their learners. A teacher working with a new class of learners whose level is already A2 or B1, for example, may start by using the language passport to conduct a rapid audit of the languages and cultural identities present in her class and the self-assessment grid to focus on the communicative skills her learners have already mastered. She may then turn to the checklists in the language biography to identify more precise learning targets for the term, using checklist descriptors to build a programme for the whole class and to negotiate learning agendas with individual students. From time to time pages in the language biography will be used as a focus for more general reflective exchanges, for instance on cultural dimensions of the English language as it is used in Ireland or on students' different learning preferences and learning styles. As the term progresses, the dossier will be used to record the learning that happens day by day and to store work in progress. Once a week students will return to the checklists and review group and individual progress from the perspective of agreed learning outcomes. This activity is undertaken in small groups, and learners are expected to be able to demonstrate their mastery of new material or skills. In this way self-assessment is embedded in peer-assessment, which in turn is embedded in the interactive reflection that frames each lesson. Occasionally we have classes of learners whose level of English is zero and who have absolutely no literacy skills in any language; they come very slowly into the ELP dossier via a series of simple worksheets. But sooner or later each page of the Milestone ELP is used in all our classes as a focus for learning, and our teachers have developed an enormous wealth of worksheets and learning activities that lead into or out of the ELP.

What are the advantages of all this for learners? Any form of portfolio learning encourages reflection and supports the development and exercise of learner autonomy, but the ELP offers more than this because it relates learning process and learning outcomes to the empirically derived proficiency scales of the CEFR. The descriptors in the checklists help learners to see themselves as autonomous users of English whose continuously expanding capacity can be measured against an internationally accepted metric. In IILT's courses, moreover, ELPbased learning merges with the portfolio-based approach to assessment adopted by FETAC 
(Further Education and Training Awards Council), the accreditation body for adult education in Ireland. Some of the projects our learners work on coincide with FETAC modules, which means that at the end of their course they have their ELP but also certificates that carry credit within the Irish adult education system and are exactly the same as those awarded to native speaker adult learners. In other words, externally moderated portfolio assessment becomes an instrument of integration.

What are the advantages for teachers? For one thing, the ELP makes it easier to manage learners' transition from one class to another. We never close, except for a few days at Christmas and New Year, because if you're a refugee learning the language of the host community it doesn't make sense to take time off. We divide the year into four terms of 12-13 weeks, and (as I explained earlier) learners are typically with us for between six and twelve months; so most of them move upwards, from one teacher to another, at least once. When they get to their second term and they are negotiating the term's programme with a new teacher, they can use their ELP as a basis for working out what they need and want to learn. Also, we quickly found that the ELP helps teachers to share experience, discuss problems, and develop approaches; and newly recruited teachers find that the ELP helps them to understand and engage with our autonomy ethos. For example, one new teacher had to use the ELP on her first day with a new class; half of the students were new to IILT and the other half had used the ELP in their previous class. So she said to those who hadn't seen it before, 'Now, in this class we're going to use something called the European Language Portfolio and these students have been using it, and they're going to tell you how to do it.' In that way she too found out a lot about the ELP. In general we can claim that the Milestone ELP has come to embody the principles of learner involvement, learner reflection and target language use.

\subsection{L2 English in Irish primary schools}

My second example has to do with the teaching of L2 English in Irish primary schools. Since the 1990s large numbers of immigrants have come to Ireland, among them of course IILT's adult students. Whatever the status of their parents, all children and adolescents resident in the state are required to attend school. There are currently about 12,000 pupils in primary schools whose first language is neither English nor Irish. The Department of Education and Science funds L2 English support on a withdrawal basis - pupils are taken out of the mainstream class, usually for one lesson a day - for two years per pupil. By the end of the school year 2006-07, there were expected to be 1,450 special L2 English teaching posts in the primary sector, so it's an area of major government investment. In the year 2000, IILT was given responsibility for designing the curriculum, developing learning and teaching supports and assessment instruments, and mediating these to teachers via in-service seminars.

When we set out to design the primary L2 English curriculum, we were clear that it must reflect the purpose of L2 English support, which is to give pupils access to the mainstream curriculum. We also wanted it to capture learning progression in a way that would correspond to teachers' experience. We knew that teachers would not use it unless it was relatively brief and clearly presented, and we also knew that it needed to support a communicative 
pedagogy and the development of communicative learning materials. Finally, it must foster the development of learner autonomy because newcomer pupils spend $85 \%$ of their time in the mainstream class, so from the beginning they must be encouraged to continue their language learning in the absence of their L2 English teacher rather than sitting surrounded by noise they don't understand. The CEFR offered itself as a very obvious model and source for constructing a curriculum that would meet those criteria, and we came up with what we call English Language Proficiency Benchmarks (IILT 2003). They are a reworking of the first three levels of the CEFR (A1, A2, B1) to make them age-appropriate and domain-specific. Part I of the Benchmarks comprises two grids (set out exactly like the self-assessment grid in the CEFR): global benchmarks of communicative proficiency - what the learner can do at the three levels in listening, reading, spoken interaction, spoken production and writing; and global scales of underlying linguistic competence - vocabulary, grammar, phonology and orthography. Then in part II we have thirteen grids, so-called units of work, which restate the behavioural capacities captured in the global benchmarks, but in terms of recurrent curriculum themes: Myself: Our school; Food and clothes; Colours, shapes and opposites; People who help us; Weather; Transport and travel; Seasons, holidays and festivals; The local and wider community; Time; People and places in other areas; Animals and plants; Caring for my locality. For a fuller account of the Benchmarks, see Little \& Lazenby Simpson (2004).

Having designed the curriculum, we decided to develop a version of the ELP as a key learning support (IILT 2004). The language passport focuses on the pupil's linguistic identity: what languages she knows, when she uses them, and with whom. As in the case of the Milestone ELP, these pages are not filled out all at once but are returned to at regular intervals, so that pupils gradually develop a sense of their identity in relation to the English language and the Irish educational system. An interesting object lesson for Irish parents is the rapidity with which newcomer pupils record that they can speak Irish. As in all ELP models, the language passport provides for regular summative self-assessment (necessarily teachersupported, of course) against descriptors derived from the English Language Proficiency Benchmarks. The language biography focuses on the pupil's daily exposure to language in the environment and on learning how to learn. Again these pages are not filled in once and for all, but revisited whenever it seems to the teacher appropriate to do so. The language biography also provides detailed goal-setting and self-assessment checklists for the thirteen units of work - altogether 211 'I can' statements that define the curriculum in behavioural terms calculated to empower the learner. Self-assessment is not a matter of learners simply ticking off the tasks they claim they can perform. It is an interactive process guided by the teacher, supported by peer assessment, and validated by the evidence that learners provide in support of their claims. It plays a crucial role in developing learners' metacognitive and metalinguistic awareness. Finally, the dossier has a table of contents page, open pages related to the units of work, and additional worksheets (e.g. on clock time, days of the week, etc.). As always it's also a place to keep finished work.

Since primary English language support is a matter of withdrawing pupils from their mainstream classroom, usually for one lesson a day, language support groups are mostly specific to a particular class or year level. Within this framework, one teacher with whom we have worked closely uses the benchmarks to plan her teaching for the school year. They enable her to identify themes, select learning activities and materials, and identify learning 
outcomes for pupils of different ages and at different stages of L2 English development. Her choice of thematic focus at any particular time depends on the programme that is being followed in her pupils' mainstream classes. At different points in the school year, she also uses seasonal themes - Halloween, Christmas, the arrival of spring - as the basis for projects to which all her language support pupils contribute. Every two or three weeks she spends a few minutes with each language support group reviewing the work they have done - the themes they have addressed, the learning activities they have performed, and the learning outcomes they have achieved. She selects one or two descriptors from the ELP checklists that reflect these outcomes and invites her pupils to consider how well they can perform the tasks involved. Take, for example, a descriptor from the A2 checklist for the theme Myself: 'I can answer lots of questions about myself'. A pupil demonstrates that she can do this by giving as many examples as possible of relevant questions and answers. The teacher then draws her pupils' attention to descriptors in other A2 checklists that have to do with asking and answering questions - perhaps 'I can ask and answer questions about drinks and foods' (Food and clothes), 'I can ask questions about colours, shapes, size and opposites' (Colours, shapes and opposites), or 'I can ask questions about the jobs that people do to help us' (People who help us). Sometimes pupils find that they can perform the relevant tasks even though the tasks have not been a specific learning target; sometimes identifying the need to expand their repertoire into another thematic area marks the beginning of a new phase of learning.

Using the ELP in this context brings two advantages. First, it embodies in a very concrete way the dynamic nature of the L2 English curriculum, making it visible to L2 English teachers, learners, class teachers, principals, school inspectors and parents. Secondly, it makes clear to the same stakeholders an approach to L2 teaching and learning that emphasizes learner involvement, learner reflection, and communicative use of the target language. In other words, it places at centre stage a version of the CEFR's action-oriented approach to language use and language learning that captures the evolving features of autonomous learner-users of L2 English.

\section{Conclusion}

The experience that I've briefly described in this talk confirms beyond any reasonable doubt that the ELP can foster the development of language learner autonomy as I understand it, by supporting learners in goal setting, self-assessment and other forms of reflection on language learning and language use, and by supporting teachers who are new to the concept of learner autonomy and its implementation in the classroom. The same experience confirms that the ELP can help to make visible the process and content of L2 learning that is shaped by the principles of learner involvement, learner reflection and target language use.

It is necessary, however, to enter two caveats. First, the ELP will help us to 'widen the circle' only if we embed it in the right way and give it the right kind of support. As I have explained, the ELP is an obligatory support in all IILT's courses for adult learners of L2 English. If it had not been obligatory, I very much doubt whether teachers would have grappled in such a productive way with the challenges that the ELP poses. Compulsion, however, is clearly difficult to impose in public educational environments. The ELP for primary L2 English 
learners in Ireland is very widely used - since we revised it in 2004, we've given away, and latterly sold, more than 15,000 copies. It has achieved this level of use not because teachers are intent on the development of learner autonomy or attracted by the idea of using a tool devised by the Council of Europe, but because it mediates the curriculum to learners in an accessible way, is the foundation for a very substantial array of learning and teaching resources, and supports forms of peer- and self-assessment that are fully harmonious with the official tests - which IILT also designed (Little 2005).

The second caveat is this. The development of learner autonomy is not the only thing the Council of Europe hopes to achieve via the ELP. It's also designed to record all of an individual's language learning, including learning that takes place outside formal education; to promote the concept of plurilingualism and its adoption as a general educational goal; to support the development of intercultural awareness; and to encourage lifelong language learning. Sometimes in Strasbourg my colleagues show signs of impatience when I talk yet again about the ELP in its pedagogical function, in relation to what happens between teachers and learners, sooner or later mentioning learner autonomy. The point, however, is that unless you can make the ELP work as a pedagogical tool that promotes the development of learner autonomy on a large scale, it is unlikely to achieve these other goals.

\section{References}

Authentik (2001). European Language Portfolio/Punann na dTeangacha Eorpacha (Model for post-primary language learners; Council of Europe accreditation number 10.2001). Dublin: Authentik.

Council of Europe (2001). Common European Framework of Reference for Languages: Learning, Teaching, Assessment. Cambridge: Cambridge University Press. [Available at http://www.coe.int/lang, section 'Common European Framework of Reference for Languages'.]

Council of Europe (2006). A user's guide to the European Language Portfolio reference documents. Strasbourg: Council of Europe. [Available at http://www.coe.int/portfolio, section 'Procedure for validation'.]

Dam, L. (1995). Learner autonomy 3: From theory to classroom practice. Dublin: Authentik.

Deci, E. L. (with R. Flaste) (1995). Why we do what we do. New York: Penguin.

Frith, U. (1989). Autism. Oxford: Blackwell.

Holec, H. (1981). Autonomy and foreign language learning. Oxford: Pergamon. [First published 1979, Strasbourg: Council of Europe.]

IILT (2003). English Language Proficiency Benchmarks for Non-English-speaking Pupils at Primary Level. Dublin: Integrate Ireland Language and Training.

IILT (2004). European Language Portfolio (Model for primary learners of English as a second language; Council of Europe accreditation number 11.2001 (rev.)). Dublin: Integrate Ireland Language and Training.

Lantolf, J. P. (ed.) (2000). Sociocultural theory and second language learning. Oxford: Oxford University Press.

Lantolf, J. P. \& S. L. Thorne (2006). Sociocultural theory and the genesis of second language development. Oxford: Oxford University Press.

Little, D. (1991). Learner autonomy 1: Definitions, issues, problems. Dublin: Authentik.

Little, D. (2001). We're all in it together: Exploring the interdependence of teacher and learner autonomy. In L. Karlsson, F. Kjisik \& J. Nordlund. (eds.), All together now. Helsinki: University of Helsinki, Language Centre, 45-56.

Little, D. (2005). The Common European Framework and the European Language Portfolio: Involving learners and their judgements in the assessment process. Language Testing 22.3, 321-336.

Little, D. (2007). Language learner autonomy: Some fundamental considerations revisited. Innovation in Language Learning and Teaching 1.1, 14-29.

Little, D. \& R. Perclová (2001). European Language Portfolio: Guide for teachers and teacher trainers. Strasbourg: Council of Europe. [Available at http://www.coe.int/portfolio, section 'Documentation'.] 
Little, D. (2006). The Common European Framework of Reference for Languages: Content, purpose, origin, reception and impact. Language Teaching 39.3, 167-190.

Little, D. \& B. Lazenby Simpson (2004). Case study 1: Using the CEF to develop an ESL curriculum for newcomer pupils in Irish primary schools. In K. Morrow (ed.), Insights from the Common European Framework. Oxford: Oxford University Press, 91-108.

Little, D., J. Ridley \& E. Ushioda (2002). Towards greater learner autonomy in the foreign language classroom (Report on an Irish research-and-development project 1998-2001). Dublin: Authentik.

Salmon, P. (1998). Life at school: Education and psychology. London: Constable.

Ushioda, E. (1996). Learner autonomy 5: The role of motivation. Dublin: Authentik.

Ushioda, E. \& J. Ridley (2002). Working with the European Language Portfolio in Irish post-primary schools: Report on an evaluation project (CLCS Occasional Paper 61). Dublin: Trinity College, Centre for Language and Communication Studies. [Available at http://www.tcd.ie/slscs/clcs, section 'Featured research, European Language Portfolio'.]

DAVID LiTTLE retired recently as Head of the School of Linguistic, Speech and Communication Sciences and Associate Professor of Applied Linguistics at Trinity College Dublin. His principal research interest is the theory and practice of learner autonomy in L2 education. From 2001 to 2008 he was Director of Integrate Ireland Language and Training, a government-funded unit that provided English language courses for adult newcomers with refugee status and supported the learning of L2 English in Irish schools. He is currently chair of the Council of Europe's European Language Portfolio Validation Committee. His numerous publications on learner autonomy include Learner autonomy 1: Definitions, issues and problems (Authentik, 1991). 